Review Essay

\title{
THE MISSION OF CULTURAL CREATION
}

\section{Lorraine V. Aragon}

\begin{abstract}
Albert Schrauwers. Colonial "Reformation" in the Highlands of Central Sulawesi, Indonesia, 1892-1995. Toronto: University of Toronto Press, 2000. xiii +279 pp.
\end{abstract}

Albert Schrauwers's book on missionization in eastern Central Sulawesi neatly bounds its subject between the end of the nineteenth and the end of the twentieth centuries, two fin de siècle moments. His incisive portrayal of how Protestant missionaries brought sociopolitical transformation to the Lake Poso region during that one hundred years illuminates an interesting Indonesian case of religious rationalization. It also invites reflection on the transformation from early ethnographies written by missionary-scholars such as A. C. Kruyt, a key figure in this book, to late twentieth century postmodern versions of the genre such as Schrauwers provides.

The colonialist endeavors of Kruyt are deciphered well in this book, even though the author, like most of us who work in Sulawesi, inevitably utilizes some of Kruyt's data to construct his own arguments. How then does contemporary ethnography honestly situate itself against the professional "ancestor" that it now upbraids? Schrauwers's answers to these questions define the scope of his investigations and descriptions. They also represent one of the prominent solutions to the "predicament of culture," which leads recent scholars to distrust the "ethnographic authority" claimed by the last century's authors. ${ }^{1}$

\footnotetext{
1 James Clifford, "On Ethnographic Authority," in The Predicament of Culture: Twentieth-Century Ethnography, Literature and Art (Cambridge: Harvard University Press, 1988), pp. 21-54.
} 
Beginning in the late 1800s, a distinguished series of European naturalists and explorers "discovered" and dutifully described the flora, fauna, and societies of interior Sulawesi, the island then called Celebes. ${ }^{2}$ The most prolific and scholarly missionary team dispatched there, Albertus C. Kruyt and Nicolaus Adriani, advocated and proliferated the label "Toraja" to describe the interior tribes. ${ }^{3}$ By no small coincidence, this classification ethnically distinguished all potential Christian converts in the highlands from incipient Muslim groups inhabiting the neighboring lowlands. The Central Sulawesi communities targeted by Kruyt and Adriani's Protestant mission near Lake Poso were termed the Bare'e-speaking Toraja. ${ }^{4}$ The colonialist creation of a core cultural identity among the Bare'e Toraja, who now call themselves Pamona, is the over-arching theme of Schrauwers's mission history and peasant economy research.

Like many other interior groups in the Netherlands Indies, the precolonial Bare'e Toraja practiced headhunting rituals as part of their regional combat and religious propitiation. ${ }^{5}$ They engaged in various offering rituals directed towards ancestors and other localized spirits, an orthopraxy which A. C. Kruyt described as a model of primitive animism in the Netherlands Indies. ${ }^{6}$ The Bare'e, however, were distinguished from other comparable "tribes" by some unusual traditions, including female ritual leaders, secondary burials with ornamented bone bundles, and intricately painted barkcloth clothing denoting social status and ritual occasion. Between the 1890s and early 1930s, thousands of examples of the unique material culture of the region were collected and ultimately deposited in ethnographic collections located primarily in Europe. 7

Among all these collections of objects and documentation of Central Sulawesi practices, the Bare'e Toraja identified by Kruyt and his linguist partner Adriani were the most extensively described local "culture." It is precisely the raw assumption of

\footnotetext{
2 See Paul Sarasin and Fritz Sarasin, Reisen in Celebes aus gefuihrt in den Jahren 1893-1896 und 1902-1903, 2 vols. (Weisbaden: Kreidel, 1905); Albert Grubauer, Unter Kopfjägern in Central-Celebes: Ethnologishe Streifzüge in Südost- und Central-Celebes Von Professor Albert Grubauer (Leipzig: R. Voigtlanders, 1913); E. C. Abendanon, Midden-Celebes Expeditie: Geologishe en Geographishe Doorkruisingen van Midden-Celebes (1909-1910), 4 vols. (Leiden: E. J. Brill, 1917-1918; and, Walter Kaudern, Ethnographical Studies in Celebes: Results of the Author's Expedition to Celebes, 1917-1920, 6 vols. (Göteborg: Elanders Bokytryckeri Aktiebolag, 1925-1944.

${ }^{3}$ Nicolaus Adriani and Albertus C. Kruyt, De Bare'e-Sprekende Toradja's van Midden Celebes, 3 vols. (Batavia: Landsdrukkerij, 1912), vol. 1. See also, J. Noorduyn, A Critical Survey of Studies on the Languages of Sulawesi (Leiden: KITLV Press, 1991), pp. 75-78.

4 In some villages, "bare'e" was glossed as "no." Such common terms of negation were used by colonial Dutch linguists to assess divisions among neighboring linguistic populations throughout Sulawesi.

5 On Sulawesi, see Richard E. Downs, The Religion of the Bare'e Speaking Toradja of Central Celebes (s'Gravenhage: Uitgeverij Excelsior, 1956); Richard E. Downs, "Headhunting in Indonesia," in Structural Anthropology in the Netherlands, ed. P. E. Josselin de Jong (The Hague: Martinus Nijhoff, 1977[1955]), pp. 117-149; and Kenneth M. George, Showing Signs of Violence: The Cultural Politics of a Twentieth-Century Headhunting Ritual (Berkeley: University of California Press, 1996). On Southeast Asia more generally, see Janet Hoskins, ed., Headhunting and the Social Imagination in Southeast Asia (Stanford: Stanford University Press, 1996).

6 Albertus C. Kruyt, Het Animisme in den Indischen Archipel ('s-Gravenhage: Martinus Nijhoff, 1906).

7 See Eija-Maija Kotilainen, "When the Bones Are Left": A Study of the Material Culture of Central Sulawesi (Helsinki: The Finnish Anthropological Society, 1992).
} 
this culture's existence that Albert Schrauwers challenges at the beginning of his book. For Schrauwers, the contemporary Pamona, like their Bare'e Toraja ancestors portrayed by Kruyt and Adriani, are the colonialist fabrication of an "ethnic group" or "culture" required by a hegemonic Dutch Indies empire and Protestant mission. Thus, the distinctive precolonial practices and material creations acclaimed by early European writers are virtually absent from Schrauwers's book. They represent for the author only a dead past that echoes today as an imaginary adat or "discursive traditionalism," which "ignores the administrative practices in which it was embedded." (p. 71)

Schrauwers views Kruyt critically as a totalizing social evolutionist of his time, the 1890 s, much as Schrauwers shows himself to be a power-sensitive particularist of his time, the 1990s. Schrauwers's book begins by reexamining and exposing the Dutch colonial discourse for what it really was-a science and ethics to support a mercantile and centralized administration-and what it was not-a dispassionate effort at human classification and godly noblesse oblige. This task has been done by others both for Central Sulawesi and elsewhere, but Schrauwers attacks his project with analytic stealth and creative argumentation. ${ }^{8}$

Part One of Schrauwers's book meticulously describes the path of Kruyt's mission and its strategic incorporation of Pamona feasting and political leaders into the local church hierarchy. The author's analysis is grounded in the European history of the Dutch Reformed Church, the progenitor of the Christian Reformed Church he knew as a youth in Canada. Schrauwers focuses particularly on the nineteenth-century "pillarization" between Protestants and Catholics in Holland. 9 This background helps explain the drive by Dutch missionaries such as Kruyt, for whom the separation of church and state was neither a reality nor a desirable goal, to foster a "Christian ethnic identity" among Central Sulawesi animists. Schrauwers argues that the Pamona people are essentially the ethnic consequence of Dutch mission policies to create a Christian community (volkskerk, Dutch) in eastern Central Sulawesi, a Dutch-allied native margin to their potentially threatening Muslim neighbors.

Here Schrauwers follows the lead of recent anthropologists for whom the idea of "a culture" is not just a heuristic overstatement of homogeneity, but a legacy of motivated colonial reinterpretations and erasures of customary practices. Schrauwers's acknowledged theoretical guide is John Pemberton, whose innovative deconstruction of "Java" is the model for Schrauwers's reconstruction of the colonial invention of the "To Pamona." 10 Schrauwers states that "totalizing representations of the To Pamona as

\footnotetext{
${ }^{8}$ See Joost J. P. Coté, "The Colonization and Schooling of the To Pamona of Central Sulawesi, 1894 to 1924" (Master's thesis, Monash University, 1979); Joost J. P. Coté, "Colonizing Central Sulawesi: The 'Ethical Policy' and Imperialist Expansion, 1890-1910," Itinerario 20, 3 (1996): 87-108; Lorraine V. Aragon, "Twisting the Gift: Translating Precolonial into Colonial Exchanges in Central Sulawesi, Indonesia," American Ethnologist 23, 1 (1996): 43-60; and Lorraine Aragon, Fields of the Lord: Animism, Christian Minorities, and State Development in Indonesia (Hawai'i: University of Hawai'i Press, 2000).

${ }^{9}$ See Peter van Roorden, "History, the Nation, and Religion: the Transformations of the Dutch Religious Past," in Nation and Religion: Perspectives on Europe and Asia, ed. Peter van der Veer and Hartmut Lehmann (Princeton: Princeton University Press, 1999), pp. 96-111.

10 John Pemberton, On the Subject of "Java" (Ithaca: Cornell University Press, 1994). "To" means "those from" or "those of" in Sulawesi languages, and Schrauwers retains the gloss "To Pamona" for Pamona people throughout the book.
} 
'To Pamona' are part of the authoritative discourses of the state, the church, and Western social sciences." (p. 12) Thus the introductory critique is directed squarely against Anthropology itself, of which Kruyt is portrayed as an early fellow practitioner of our universalizing and exoticizing discourses. (pp. 10-16)

Schrauwers delineates and contrasts the two hegemonic discourses by which the Pamona have been defined. The Dutch Reformed Church's vision of a Pamona Christian community or traditional culture, fostered ironically through the modernizing mission organization (pp. 42, 63-64, 77), is compared with the New Order government's vision of Pamona culture (kebudayaan) as outmoded songs and other supposed regional manifestations of ancient pan-Indonesian artistic traditions (pp. 78, 88-90). For Schrauwers, these are both invented regional forms of nationalism designed to serve the ruling government. The problems that the concept of a "Christian Pamona adat" pose to the late New Order regime's effort to depoliticize ethnic and religious identities are explored throughout the book as ironic tension points between church and state (pp. 64, 88-93, 238-241).

Part Two of Schrauwers's book shifts from historical reconstruction based primarily on Dutch archival sources to a contemporary economic analysis of Pamona households based on the author's early 1990s fieldwork in the Tentena area. The author draws his information from fieldwork in the Pamona Utara subdistrict (kecamatan) and particularly from a survey of sixty-eight related households in four villages. (p. 101) Schrauwers argues that Pamona households have vague boundaries, because many children are fostered by kindred other than their parents. He concludes that fosterage, while appearing to be part of Pamona "traditional" kinship patterns, actually is the result of the increasingly uneven capitalization of wet-rice land.

On the basis of these data, the author challenges both Clifford Geertz's "shared poverty" model and James C. Scott's "moral economy of the peasant" model.11 Schrauwers argues that what Geertz and Scott saw as "traditional" patterns of familial sharing, operating apart from impinging capitalism, only emerged "in the context of capitalist transformation, class differentiation, and historical attempts to create an economically rational peasantry." (p. 98) Schrauwers cleverly focuses on household composition and the fact that land and labor may be differentially commodified. (p. 103)

Schrauwers finds that 44 percent of the sixty-eight households he analyzes are nuclear families, while 49 percent are extended families that are "fostering children (or other kin)." (p. 117) Following Esther Goody, Schrauwers defines fosterage as the nurturing and sponsoring of young kin in a way that does not otherwise affect their jural status or inheritance rights. ${ }^{12}$ Schrauwers observes that the colonial-driven shift from swidden to wet-rice agriculture in the Pamona region has produced a land-

\footnotetext{
11 Clifford Geertz, Agricultural Involution: The Process of Ecological Change in Indonesia (Berkeley: University of California Press, 1963); James C. Scott, The Moral Economy of the Peasant: Rebellion and Subsistence in Southeast Asia, (New Haven: Yale University Press, 1976). Schrauwers's critique extends arguments presented by Joel S. Kahn in "Indonesia after the Demise of Involution: Critique of a Debate," Critique of Anthropology 5, 1 (1985): 69-96, and Joel S. Kahn, Constituting the Minangkabau: Peasants, Culture and Modernity in Colonial Indonesia (Providence: Berg, 1993).

12 Esther N. Goody, "Forms of Pro-Parenthood: The Sharing and Substitution of Parental Roles," in Kinship, ed. Jack Goody (Hammondsworth, Middlesex: Penguin, 1971), pp. 331-45.
} 
holding capitalist class in need of additional, unpaid kin laborers, now often provided through fosterage. (pp. 107-113) Wealthier kin sponsor feasts for poorer relatives and then often seem to require the subordinate relatives' children to become free labor in return. (p. 152)

In Schrauwers's eyes, fosterage takes on a somewhat sinister tone. He provides an example of a young cousin being treated like "a servant," a Central Sulawesi version of "Cinderella." (p. 119) Fosterage among the Pamona is seen as a way that the poor "lose" their children, while wealthier kindred can claim them and leave the biological parents' house "denuded." (pp. 118-120) The potential of fosterage to assist children and their biological parents temporarily, as well as to allow for reciprocation on a generation-by-generation basis, is less explored, as are any comparative measures of children's chores in the nuclear or non-fostering, extended families.

Schrauwers's data and reasoning on Central Sulawesi households and economic exchanges are alluring, yet he extends his argument beyond the data's purchase when he argues that Pamona fosterage is a recent class-based creation, instead of -as is more probable - a contemporary adaptation of much earlier kinship practices that always exchanged favors between households differentially situated in ecological, as well as economic, respects. The ubiquitous practice of fosterage even in noncapitalized, swidden communities far beyond the Pamona region implies its regional ancestry, not its abrupt appearance with Western capitalism. In various guises, it is found throughout Sulawesi, Indonesia, Malaysia, Thailand, the Philippines, even farther afield in Oceania. ${ }^{13}$ Schrauwers does not consider these comparative data on Southeast Asian fosterage, which attest to more symbiotic aspects, as well as the ability of unmarried young people, even children in some areas, to select their preferred household residences.

The use of the term "denuded" to refer to houses where minors are not coresident with their biological parents (p. 249 n. 7) also seems to elevate the Western ideal of a nuclear family beyond its rightful status and applicability in Southeast Asia. Despite his general criticism of the source, Schrauwers uses only Kruyt's lack of discussion about fosterage to support his own claim that "fosterage is a relatively new phenomenon among the To Pamona." (p. 119, p. 249 n.8) In sum, while Schrauwers's analysis suggests interesting ways to view Pamona fosterage as a means to address feasting hierarchies and capitalist forms of land or labor shortages, Schrauwers's conclusions about the kinship institution's recency and unilateral exploitation can only be made in the absence of historic or ethnographic comparison.

In Part Three, Schrauwers focuses on the political process by which Kruyt's mission created a Christian ethnic community. Schrauwers argues that the Pamona community

${ }^{13}$ See Clark E. Cunningham, "Atoni Borrowing of Children: An Aspect of Mediation," in Proceedings of the American Ethnological Society, ed. Melford Spiro (Seattle: University of Washington Press, 1964), pp. 2137; Janet Carsten, "Children in Between: Fostering and the Process of Kinship on Pulau Langkawi, Malaysia," Man 26, 3 (1991): 425-43; Ivan Brady, ed., Transactions in Kinship: Adoption and Fosterage in Oceania (Honolulu: University of Hawaii Press, 1976); and an overview in Shuichi Nagata, "Conjugal Families and the Non-Circulation of Children in a Resettlement Community of Foragers in West Malaysia," in Structuralism's Transformations: Order and Revision in Indonesian and Malaysian Societies, ed. Lorraine V. Aragon and Susan D. Russell (Tempe: Arizona State University Program for Southeast Asian Studies, 1999), pp. 37-67. 
is not characterized by the reorientation of their shared beliefs, but rather by the incorporation of their indigenous political processes into the Protestant church's local bureaucracy and ritual format. (p. 172-73) Most interesting here is the way Schrauwers documents the transitions: of kindred leaders (kabosenya) into church elders, of elders' rituals of advice (monuntu) into Protestant sermons, and of indigenous female religious leadership into the church women's group (Komisi Wanita). By following these transformations into the late New Order milieu, this book organizes important data and perspectives on Indonesia's recent religious and cultural politics.

Given the communal violence between Pamona Christians and Muslims that has shaken the Poso region between 1998 and 2000, one looks to Schrauwers's book for insights or even premonitions about these disturbing events. Despite Schrauwers's focus on power and hegemony, there are only scattered clues concerning the upcoming turmoil. Schrauwers notes the inclination of Dutch colonial officials to separate Christian and Muslim communities. He also makes some references to stinging Pamona recollections of the Darul Islam and Permesta periods. (pp. 13, 82-86) Schrauwers's discussion of incipient class divisions and differential land holdings in the Pamona area might present a possible motive for local conflict, yet the portrayal of kindreds and their mystifying ideology of sharing includes no accounts of related communal dissension. Only his description of the 1997 political campaign prior to Suharto's resignation refers to Christian versus Muslim threats. (pp. 91, 226-227) Indeed, the recent communal violence in the Pamona region occurred well after Schrauwers's early 1990s fieldwork.

At the end of Schrauwers's book, the reader knows much about the "To Pamona" as an historical creation, yet far less about their daily lives or concerns. As this book makes clear, however, we cannot return to the colonial era ethnographies with the same sense of unabashed curiosity as earlier readers. For therein lies an imperialist view of "ancient history," now used mainly by contemporary scholars such as Schrauwers to reconstruct the conditions of that history's authorship and process. The hundred years of difference, however, warrants consideration not only about what happened to the Bare'e, now Pamona, but also about what has happened to us.

The 1970s-1990s critique of empiricist and structuralist ethnography, which itself generated a form of "pillarization" within recent anthropology, has been documented and cited extensively. ${ }^{14}$ Less noted is that the critique of purportedly objective discourse unleashed some disparities in pragmatic responses. Ethnographers such as Anna Tsing respond by inscribing and relaying local commentaries from less powerful, "marginal" populations. By contrast, Schrauwers argues that he has no business transmitting "indigenous voices." 15 Schrauwers notes obliquely that ordinary Pamona

\footnotetext{
14 Edward W. Said, Orientalism (New York: Pantheon Books, 1978); George E. Marcus and Michael M. J. Fischer, Anthropology as Cultural Critique: An Experimental Moment in the Human Sciences (Chicago: Chicago University Press, 1986); and James Clifford and George E. Marcus, eds. Writing Culture: The Poetics and Politics of Ethnography (Berkeley: University of California Press, 1986).

15 Anna L. Tsing, In the Realm of the Diamond Queen: Marginality in an Out-of-the-Way Place (Princeton: Princeton University Press, 1993). On the range of responses to structuralism in Southeast Asia, see Lorraine V. Aragon and Susan D. Russell, "Delineating Theoretical Approaches in Southeast Asian Anthropology," in Structuralism's Transformations, ed. Lorraine V. Aragon and Susan D. Russell, pp. xxiiilxii.
} 
people showed some reluctance to become "involved" in his research by speaking openly of their situation. He explains that he refrained from describing matters they asked he not write down in his notebooks. (pp. 12-13, 245) He vows instead to describe the historic power structures of church and state, following the paths of Talal Asad and John Pemberton, and not to describe quaint customs or speak for those excluded from the realms of power. (p. 11-13) ${ }^{16}$

Schrauwers's sharp vision could have served any theoretical model well, but its achievements particularly satisfy Laura Nader's early admonition to "study up" the power hierarchy. ${ }^{17}$ Yet a disciplinary shift occurs when describing the concerns and actions of those with less access to power becomes not only a too obvious or politically hazardous goal, but theoretically inadmissable. If this perspective suppresses others, ethnographers will do less of the hard work collecting new data about the unfamiliar or the quiet. Ultimately, that would make anthropology, not to mention the study of religion, a more minimalist project, someplace where the lives of distant but ordinary individuals with cross-cutting interests rarely would be seen. Schrauwers is correct to label the ritual-as-culture views held by colonialist ethnographers and the Suharto state as skewed, but much of Pamona culture here becomes a lacuna in the present, whose absence is extrapolated from the politics of the past.

Schrauwers dismisses any sentimental backtracking on the study of past or present populations. "Salvage ethnography' is dead," he states definitively. (p. 14) Schrauwers also warns his reader at the outset of his book that he offers "no riveting portraits of village life, no complete (and totalizing) discussions of 'the' kinship system, gender, or cosmology." (p. 13) The human portraits and far-ranging cultural explorations indeed are not there, although Schrauwers's economic analysis of Pamona households is locally complete in its Machiavellian rationale.

Overall, Schrauwers delivers well on his promise to make sense of certain past and present conflicting discourses of church and state in Indonesia, and his book is a model of deliberate argumentation. We finish the volume knowing more about Kruyt's mission of cultural creation, and perhaps about ourselves as neo-colonialist scholars. Yet, we know relatively less about eastern Central Sulawesi people, either as groups or individuals, because their presence in ethnography seems less distinctive and more shadowy than it was roughly one hundred years ago.

16 Talal Asad, "Anthropological Conceptions of Religion: Reflections on Geertz," Man n.s. 18, 2 (1983): 237-59, and Genealogies of Religion: Discipline and Reasons of Power in Christianity and Islam (Baltimore: Johns Hopkins University Press, 1993); Pemberton, On the Subject of 'Java.'

${ }^{17}$ Laura Nader, "Up the Anthropologist--Perspectives Gained from Studying Up," in Reinventing Anthropology, ed. Dell H. Hymes (New York: Pantheon, 1972), pp. 284-311. 
